\title{
A abordagem do ensino com pesquisa: uma alternativa pedagógica para o ensino de biblioteconomia e ciência da informação
}

\section{The approach to teaching with research: a pedagogical alternative for the teaching of library and information sciences}

Mara Eliane Fonseca RODRIGUES'

\section{RES U M O}

Pesquisa que se apoia nos fundamentos do paradigma emergente para repensar as práticas pedagógicas adotadas pelos professores das áreas de Biblioteconomia e Ciência da Informação. Procura articular as concepções pedagógicas subjacentes à formação de professores com a concepção da pesquisa como princípio metodológico no ensino. Verifica, por meio de entrevistas, como o professor-pesquisador que atua nessas áreas desenvolve sua prática pedagógica a fim de estabelecer até que ponto os processos de pesquisa têm sido incorporados às práticas pedagógicas desses professores. Objetiva gerar bases para uma nova didática no ensino das áreas de Biblioteconomia e Ciência da Informação, centrada no ensino com pesquisa. Por fim, tece algumas reflexões resultantes dos depoimentos colhidos.

Palavras-chave: Ensino. Ensino de biblioteconomia e ciência da informação. Paradigma emergente. Pesquisa.

\begin{abstract}
A B S T R A C T
This research relies on the fundamentals of the emerging paradigm for rethinking the teaching approaches used by professors in the areas of Library and Information Science. It aims to relate the underlying pedagogical conceptions in teacher training with the design of research as a methodological principle in education. It verifies, through interviews, how a teacher-researcher who works in these areas develops his/her teaching in order to establish to what extent the research processes have been incorporated into teaching practices. It aims to generate a new basis for teaching in Library and Information Sciences, focusing on teaching with research. Finally, it offers some reflections resulting from the reports collected.
\end{abstract}

Keywords: Teaching. Teaching of library and information sciences. Emerging paradigm. Research.

\footnotetext{
1 Professora Doutora, Universidade Federal Fluminense, Departamento de Ciência da Informação. R. Lara Vilela, 126, São Domingos, 24210-590, Niterói, RJ, Brasil.E-mail: <maraeliane121@gmail.com>. Recebido em 19/12/2009 e aceito para publicação em 8/7/2010.
} 


\section{NTRODUÇÃ O}

Hoje, vive-se em um mundo sem fronteiras, de pluralidade cultural, que, ao mesmo tempo, veicula conteúdos globais e realidades locais constituindo um processo dinâmico e complexo.

A literatura que aborda as questões educacionais diante desses novos fatos versa sobre a necessidade de a educação estar preparada para esses grandes desafios e que deve procurar trabalhar os conhecimentos em sua totalidade. Mas, o que se encontra na prática é "uma divisão de informações e uma educação com ênfase nos aspectos cognitivos e intelectuais" (Grinspun, 1994, p.22). A educação superior, considerada um componente essencial do sistema educativo devido à sua capacidade para transformar e induzir mudanças e avanços na sociedade sofre forte influência do paradigma mecanicista. A partir do século XIX as universidades assumem e aceitam o paradigma cartesiano-newtoniano e passam a credenciar como legitimo o conhecimento científico comprovável, racional e objetivo.

Tais referenciais alicerçaram o ensino nas universidades, levando-as a desenvolver uma formação tecnicizante. A forte influência do pensamento newtoniano-cartesiano conduziu as universidades a uma organização compartimentalizada em centros, departamentos, divisões e seções. Os cursos foram divididos em disciplinas estanques, em períodos e em séries. Essa estruturação "restringiu cada profissional a uma especialidade, impulsionando a especificidade, perdendo a consciência global e provocando o afastamento da realidade em toda sua plenitude" (Behrens, 2005, p.22).

Contudo, o paradigma cartesiano-newtoniano, sob o qual se estrutura a universidade, começa a ser questionado. Autores como Capra (1982; 1996), Prigogine (1991), Santos (1988; 1989; 1999; 2002a; 2002b) e Morin (2000a, 2000b), dentre outros, iniciam um novo processo de reflexão, a partir da necessidade de compreender o processo de construção do conhecimento e a articulação do pensamento diante das transformações por que passam as sociedades do mundo moderno. Nota-se, desse modo, a emergência de um novo paradigma que, embora se apresente sob variadas denominações, Santos (2002b) adota a denominação paradigma emergente ${ }^{2}$; Prigogine (1991) e Capra (1996) usam a expressão paradigma sistêmico; Morin (2000b) qualifica de paradigma da complexidade. Em síntese esse novo paradigma tem como pressuposto básico romper com a ideia de um saber parcelado, fragmentado, gerado pelo paradigma newtoniano-cartesiano. O que está em debate, portanto, é a necessidade da busca de sentido para o ensino contemporâneo, numa perspectiva não fragmentária.

Com base nos fundamentos do paradigma emergente, apresenta-se algumas reflexões em torno de uma proposta de ensino-aprendizagem para as áreas de Biblioteconomia e Ciência da Informação, que possa apontar para uma resignificação desse processo.

Essa proposta, por sua vez, baseia-se no trabalho desenvolvido nos últimos anos no ensino de graduação com a perspectiva de superar um modelo de educação tradicional, voltada para a transmissão e transferência de conhecimentos. Tem-se buscado, ao longo dos últimos anos, alcançar uma proposta de educação transformadora que leve em conta a experiência de cada um dos sujeitos da ação educativa, visando à formação integral do estudante (Rodrigues; Breglia, 2001; Rodrigues, 2002a; 2002b; 2002c; Rodrigues et al., 2002; Rodrigues; Dumont, 2004).

No transcorrer desse trabalho, compreendeu-se a necessidade de intervir nos currículos, em função de se configurarem como o instrumento principal da veiculação do saber universitário, e, também, nas práticas pedagógicas adotadas pelos professores como forma de potencializar novas experiências no processo de formação.

Sabe-se que nos tempos atuais, a competência profissional transcende os limites da mera aptidão técnico-científica e adentra o campo do político-social levados pelo fato de que

A sociedade passa a exigir profissionais que tenham capacidade de tomar decisões, que sejam autônomos, que produzam com iniciativa própria, que saibam trabalhar em grupo, que partilhem suas conquistas e que estejam em constante formação (Behrens, 1999, p.386).

Mas, quando se faz referência ao bibliotecário, a imagem que emerge é a de um profissional

\footnotetext{
2 Para fins deste estudo, adota-se a denominação cunhada por Boaventura Santos: paradigma emergente, por se entender que melhor incorpora a ideia de mudança de um modelo para outro, a qual denomina-se transição paradigmática.
} 
eminentemente técnico, pois sua formação está associada

\begin{abstract}
A um modelo de ensino transferidor de conhecimento, associado a manuais, livros didáticos, sistemas e instrumentos de gestão de informação que são tomados mais como objetos para serem repassados em estado final, do que como objetos para serem criticamente repassados como saber transitório e passível de assimilação e transformação no meio ao qual se destina (Souza, 2004, p. 16).
\end{abstract}

No Brasil, particularmente, esses profissionais são formados e capacitados tanto em cursos de graduação em Biblioteconomia, quanto em cursos de pós-graduação em Ciência da Informação. No sistema brasileiro, a formação em Biblioteconomia e Ciência da Informação é oferecida em diferentes níveis: "o perfil do bibliotecário é formado em cursos de graduação, já os mestres e doutores em Ciência da Informação são titulados em cursos de pós-graduação stricto sensu" (Oliveira, 2005, p.26).

Oliveira e Araújo (2002), ao analisarem a literatura sobre a formação profissional dessas áreas, observaram que se baseiam em orientações paradigmáticas diferenciadas, o que acaba gerando variadas dificuldades durante o processo formativo. Consideraram que "estamos trabalhando em uma área em mudança motivada por fatores internos e externos. O fator externo de maior impacto é, sem dúvida, o das novas tecnologias" (Oliveira; Araújo, 2002, p.43).

Diante dessas considerações, o exercício da docência reveste-se de valor e significado até então pouco considerados. Para formar profissionais com as aptidões anteriormente referidas, o trabalho docente deve privilegiar não apenas o processo de ensino, mas sim o processo de ensino-aprendizagem, o que significa "compreender bem cada um deles para melhor entendermos como se pode fazer a correlação, a complementaridade e a integração dos dois processos, transformando-os em um só" (Masseto, 2003, p.35).

No tocante à prática pedagógica desenvolvida nos cursos de graduação de Biblioteconomia no Brasil, tais exigências encontram reflexos marcantes em um momento que se procura romper com uma formação profissional eminentemente técnica para se buscar um perfil de natureza mais interdisciplinar. A prática pedagógica deve preparar o futuro profissional para que possa ter uma melhor compreensão das ambiguidades e complexidades do tempo presente, e, deste modo, dar conta de uma realidade heterogênea, em um mundo globalizado, com usuários mais exigentes e todo um aparato tecnológico em constante aperfeiçoamento.

Portanto, para acompanhar o processo acelerado de transformações e rupturas pelo qual passa a sociedade contemporânea, é preciso que os cursos de graduação busquem um novo caminho no trabalho de formação, fundado em concepções que articulem teoria e prática. Para isso, será necessário que os professores exerçam um papel, sobretudo, motivador, alguém a serviço da emancipação do aluno, pois, é no processo formativo que se delineiam e se desenvolvem as bases para a formação do profissional crítico e reflexivo capaz de gerenciar, de modo competente e eficiente, conhecimentos específicos que levem à elaboração de novos conhecimentos ou à solução de problemas detectados em sua prática profissional.

Desse modo, o presente estudo objetiva contribuir para o repensar das práticas pedagógicas adotadas no ensino de Biblioteconomia e Ciência da Informação e gerar bases para a construção de novos procedimentos didáticos.

Entendendo que a pesquisa, assumida também como princípio educativo (Demo, 1991) é o ponto de partida para redimensionar a atual ação docente do professor universitário, em particular do professor de Biblioteconomia e Ciência da Informação, transformando o aluno em partícipe do processo construtivo do conhecimento, o referencial teórico deste estudo procura articular as concepções pedagógicas subjacentes à formação de professores com a concepção da pesquisa como princípio metodológico no ensino.

Em termos metodológicos o estudo se desenvolveu dentro da abordagem da pesquisa qualitativa, pois segundo Minayo (1997, p.22) "a abordagem qualitativa aprofunda-se no mundo das ações e relações humanas, um lado não perceptível e não captável em equações, médias e estatísticas". Desse modo, a base da investigação qualitativa reside na abordagem interpretativa da realidade social e privilegia, essencialmente, a compreensão dos comportamentos a partir dos sujeitos da investigação. 
Considerando que se pretendia verificar até que ponto os processos de pesquisa têm sido incorporados às práticas pedagógicas dos professores de Biblioteconomia e Ciência da Informação, delimitou-se que os sujeitos da pesquisa deveriam ser professores e pesquisadores atuantes em cursos de graduação em Biblioteconomia que contam com a bolsa de produtividade em pesquisa do Conselho Nacional de Desenvolvimento Científico e Tecnológico (CNPq). Essa delimitação se deve, primeiramente, às características peculiares do processo de formação das áreas de Biblioteconomia e Ciência da Informação, especialmente no Brasil, conforme já salientado. Em segundo lugar, se deve ao fato de termos constatado que esses professores estão credenciados em programas de pósgraduação pertencentes a escolas ou departamentos de Ciência da Informação também ligados a cursos de graduação em Biblioteconomia. No desenvolvimento do estudo foram realizadas entrevistas semi-estruturadas com 19 professores-pesquisadores de diferentes universidades e níveis de bolsa, abrangendo o período de 2005 a 2008.

As categorias adotadas para análise foram: a) concepções de educação, ensino e aprendizagem; b) práticas pedagógicas; c) vinculação pesquisa/ensino; d) pesquisa como procedimento pedagógico. Essa análise levou em conta o processo histórico da formação em Biblioteconomia e Ciência da Informação no Brasil, bem como procurou acompanhar, com a lógica investigativa, os caminhos e as reflexões que estão sendo percorridos por aqueles professores que, em princípio, estão dispostos a fazer rupturas paradigmáticas.

\section{AS TEORIAS PEDAGÓGICAS E O EDUCAR PELA PESQUISA}

Inicialmente é necessário dizer que teoria é aqui considerada como um conjunto sistemático de opiniões e ideias sobre um dado tema e não como um conjunto de regras ou leis aplicadas a uma área específica, tendo em vista que ainda não se pode afirmar que tenham se estabelecido teorias na educação com essa conotação a respeito da abordagem do ensino com pesquisa.

Para Pérez Gomez (1998, p.353) "a função do docente e os processos de sua formação e desenvolvimento profissional devem ser considerados em relação aos diferentes modos de conceber a prática educativa". Por isso, propõe diferentes perspectivas ideológicas para responder aos dilemas impostos à formação do docente, apontando quatro perspectivas básicas que interferem no desenvolvimento prático da função e formação do professor: perspectiva acadêmica; perspectiva técnica; perspectiva prática; perspectiva de reflexão na prática para a reconstrução social.

A perspectiva acadêmica considera que "o ensino é, em primeiro lugar, um processo de transmissão de conhecimentos e de aquisição da cultura pública que a humanidade acumulou" (Pérez Gomez, 1998, p.354). Nessa perspectiva, o docente é concebido como um especialista e sua formação estará vinculada estreitamente ao domínio das disciplinas que compõem a cultura e cujos conteúdos deverá transmitir.

Na perspectiva técnica, o ensino é avaliado pela qualidade dos produtos e na eficácia e economia de sua realização. Nessa visão, "o professor é um técnico que domina as aplicações do conhecimento científico produzido por outros e transformado em regras de atuação" (Pérez Gomez, 1998, p.356). O docente, nessa perspectiva, não necessita chegar ao conhecimento científico, mas somente dominar as rotinas de intervenção técnica que se derivam daquele.

A perspectiva prática fundamenta-se no pressuposto de que "o ensino é uma atividade complexa, que se desenvolve em cenários singulares, claramente determinados pelo contexto, com resultados em grande parte imprevisíveis e carregados de conflitos de valor que requerem opções éticas e políticas". Por isso, a experiência do exercício da docência é fundamental para o professor, ele "deve ser visto como um artesão, artista ou profissional clínico que tem de desenvolver sua sabedoria experencial e sua criatividade para enfrentar as situações únicas, ambíguas, incertas e conflitantes que configuram a aula" (Pérez Gomez, 1998, p.363). Nessa perspectiva, a formação do professor se apoiará especialmente na aprendizagem da prática, para a prática e a partir da prática.

Na perspectiva de reflexão na prática para a reconstrução social, Pérez Gomez insere os enfoques investigativos da formação docente. Nessa perspectiva, "o professor é considerado um profissional autônomo que reflete criticamente sobre a prática cotidiana para compreender tanto as características dos processos de ensino-aprendizagem quanto do contexto em que o ensino ocorre [...]" (Pérez Gomez, 1998, p.373). Nessa visão, agrupam-se aquelas posições que, mesmo com matizes diferentes, vêm o ensino como uma atividade 
crítica e como uma prática social. $\bigcirc$ autor diferencia as propostas em dois enfoques: o enfoque de crítica e reconstrução social, que se define claramente partidário de propostas didáticas que vislumbrem ações concretas de justiça, igualdade e emancipação social, em que o processo de formação tem por finalidade desenvolver a consciência dos cidadãos para uma sociedade mais justa e igualitária. Nessa perspectiva, a escola deve ter a capacidade de pensar criticamente sobre a ordem social e o professor é considerado como um intelectual transformador, compromissado politicamente. $O$ professor é, ao mesmo tempo, um educador e um ativista político, no sentido de intervir abertamente na análise e no debate dos assuntos públicos.

O segundo enfoque apontado por Pérez Gomez (1998): a investigação-ação desenvolveu-se na Inglaterra, desde o final da década de sessenta. Um dos principais representantes dessa corrente pedagógica é Schön (1995) que propôs uma nova epistemologia da prática docente baseada na reflexão-na-ação (o refletir do professor sobre sua prática) e reflexão sobre a ação (a pesquisa sobre a sua ação docente). Zeichner (1995), explica as diferentes categorias criadas por Schön para traçar uma epistemologia da prática docente.

\footnotetext{
Em primeiro lugar, a reflexão-na-ação refere-se aos processos de pensamento que se realizam no decorrer da acção, sempre que os professores têm necessidade de reenquadrar uma situação problemática à luz da informação obtida a partir da acção, desenvolvendo experiências para conseguir respostas mais adequadas. Aqui a reflexão serve para reformular as acções dos professores no decurso da sua intervenção profissional. Por outro lado, a reflexão-sobre-a-ação refere-se ao processo de pensamento que ocorre retrospectivamente sobre uma situação problemática e sobre as reflexões-na-ação produzidas pelo professor (Zeichner, 1995, p. 126).
}

Contudo, ao produzir uma síntese genérica, aplicando as suas teorias à formação de professores, Schön (1995, p.91) considera que "na formação de professores, as duas grandes dificuldades para a introdução de um praticum reflexivo são, por um lado, a epistemologia dominante na universidade e, por outro, o seu currículo profissional normativo" (Schön, 1995, p.91). Para o autor, o que dificulta formar um professor para tornar-se mais capaz de refletir na e sobre a sua prática. Considera que o caminho possível para minimizar essa dificuldade é incrementar as iniciativas que já começam a emergir e estimular a formação contínua dos professores.

Oenfoque investigativo de formação também é discutido por Freire (1996) quando propõe o exercício de uma pedagogia da autonomia. Edina Castro de Oliveira, ao prefaciar sua obra, esclarece que "a pedagogia da autonomia nos apresenta elementos constitutivos da compreensão da prática docente enquanto dimensão social da formação humana". $\mathrm{Na}$ sua proposta de uma formação docente ao lado da reflexão sobre a prática educativo-progressiva em favor da autonomia do ser dos educandos, Freire (1996, p.22, grifo do autor) alinha e discute alguns saberes que lhe parecem indispensáveis à prática educativo-crítica ou progressista. Como um desses saberes indispensáveis considera que o professor, desde o princípio de sua experiência formadora, deve assumir-se como sujeito também da produção do saber e se convencer definitivamente que "ensinar não é transferir conhecimento, mas criar as possibilidades para a sua produção ou a sua construção". Por isso, "não há ensino sem pesquisa e pesquisa sem ensino" tampouco existe docência sem discência, para ele a docência-discência e a pesquisa são indicotomizáveis, são práticas requeridas pelo ciclo gnosiológico: o em que se ensina e se aprende o conhecimento já existente e o em que se trabalha a produção do conhecimento ainda não existente. Ensinar, aprender e pesquisar lidam com esses dois momentos do ciclo.

As concepções pedagógicas, aqui apresentadas, incluem os princípios do educar pela pesquisa na formação de professores e mostram o quanto é fundamental o docente exercer a reflexão crítica sobre sua prática, pois, conforme ressalta Freire (1996, p. 19) "é pensando criticamente a prática de hoje ou de ontem que se pode melhorar a próxima prática". Essa formação coloca em destaque a preparação do professor no exercício de sua prática como ator que reflete sobre as ações que realiza cotidianamente em sala de aula, habilitando-o a usar a pesquisa como uma forma de lidar com os problemas com que se defronta no processo de ensino-aprendizagem, aprendendo a usála como instrumento principal do processo educativo. Cabe, agora, discutirmos as possibilidades que se apresentam ao professor para adotar a pesquisa como procedimento metodológico no ensino. 


\section{A PESQUISA COMO PRINCÍPIO ME- TODOLÓGICO NO ENSINO}

No campo da educação vários autores vêm aprofundando a ideia do ensino com pesquisa, entre eles Demo (1991; 1993; 1996; 1997), Cunha (1996a, 1997) e Masetto (2003).

$\mathrm{Na}$ indicação de caminhos para educar pela pesquisa, Demo (1997) tem apresentado contribuições significativas. Nesse procedimento, sustenta a ideia de que devemos elevar a pesquisa à condição de princípio educativo, tornando-a o ambiente didático cotidiano, no professor e no aluno, para desfazer a ideia de que pesquisa é uma atividade especial que somente pode ser desenvolvida por gente especial. Com essa proposta, Demo (1991) procura desmistificar a pesquisa considerando-a como princípio científico porque contribui para a construção de conhecimento e como princípio educativo porque promove o questionamento crítico e inovador.

Para promover o processo de pesquisa no aluno, numa proposta de aproximação da teoria e da prática, Demo (1997) aponta algumas estratégias com vistas a facilitar a capacidade de educar pela pesquisa. Mas, o autor alerta que seu enfoque é de "estilo metodológico-propedêutico", portanto suas propostas são apenas sinalizações sugestivas. Para ele, "cada professor precisa saber propor seu modo próprio e criativo de teorizar e praticar a pesquisa, renovando-a constantemente e mantendo-a como fonte principal de sua capacidade inventiva" (Demo, 1997, p. 15).

Para estimular a pesquisa no aluno, Demo (1997, p. 15) indica alguns passos importantes que podemos identificar como níveis crescentes de pesquisa.

Num primeiro nível pode-se destacar a importância de fazer o aluno procurar material, o que "significa habituar o aluno a ter iniciativa, em termos de procurar livros, textos, fontes, dados informações" com a finalidade de superar a regra comum de receber tudo pronto. Para Demo (1997, p.21) "a procura de material será um início instigador".

Um passo à frente, o segundo nível, representa a motivação para os alunos fazerem interpretações próprias, no sentido de tomar um texto e interpretá-lo com alguma autonomia para conferir-lhe formato interpretativo pessoal. passo seguinte, o terceiro nível, será a insistência sobre a reconstrução do conhecimento, como maneira própria de aprender. Trata-se de tomar o conhecimento disponível como ponto de partida e reconstruí-lo com manifestação própria. Aqui o que está em jogo é "menos a originalidade do conhecimento, do que sua reconstrução própria" à medida que o simples fazer é superado pelo saber fazer e pelo constante refazer até alcançar a capacidade de formulação (Demo, 1997, p.25).

A partir daí, surge o desafio da elaboração própria, que pode ser considerada o quarto nível. Nessa etapa o aluno precisa ser motivado a avançar na autonomia da expressão própria. Essa motivação não se reduz somente à elaboração de textos, inclui também "a capacidade de se expressar, de tomar iniciativa, de construir espaços próprios, de fazer-se sempre presente e participativo, e assim por diante" (Demo, 1997, p.29).

Demo (1997, p.33) ressalta, ainda, que a educação pela pesquisa requer alguns cuidados propedêuticos, tanto em relação ao aluno, como ao professor. Quanto ao aluno, para que ele desenvolva a habilidade questionadora reconstrutiva é necessário que o professor o oriente permanentemente para:

a) expressar-se de maneira fundamentada - explicar ao aluno que o discurso acadêmico difere dos outros, porque questiona com lógica e argumentação;

b) exercitar o questionamento - exigir que toda investigação seja realizada de forma sistematizada, ou seja, não vale procurar materiais sem método, colher dados sem organizá-los, citar sem contraler, etc.;

c) exercitar a formulação própria - fazer bom uso da lógica, da argumentação, da crítica e da autocríica, dentro da regra segundo a qual só se pode garantir o que de alguma forma tem base; não adianta construir algo que ninguém mais pode decifrar, ou usar linguagem particular inacessível;

d) reconstruir autores e teorias - incitar a reconhecer nos outros (autores, pesquisadores, professores) os procedimentos criativos que indicam a capacidade de questionar e reconstruir, não para imitar mas, sob o estímulo do exemplo, encontrar pistas da criatividade própria;

e) cotidianizar a pesquisa - fazer do questionamento reconstrutivo uma atitude cotidiana, de modo a tornar o ambiente acadêmico 
naturalmente positivo e estimulante, no qual a leitura constante é algo normal, a feitura de trabalho próprio é óbvia, o esforço de equipe bem organizado e produtivo é exigência evidente.

Com relação ao professor, Demo considera que "é condição fatal da educação pela pesquisa que o professor seja pesquisador". No entanto, isso não significa que o professor deva ser um "profissional da pesquisa, como seria o doutor que apenas ou sobretudo produz pesquisa específica", mas, sim, ser envolvido com a pesquisa como profissional da educação (Demo, 1997, p.38, grifo do autor).

Para contextualizar melhor esta ideia, Demo (1997) explicita para o professor cinco desafios da pesquisa com fins eminentemente educativos:

- Em primeiro lugar, aparece a necessidade indiscutível do professor reconstruir permanentemente seu próprio projeto pedagógico. Isso significa que o professor não pode circunscrever-se a mero porta-voz de teorias alheias. Precisa apresentar-se com proposta própria, elaborada e sempre reelaborada o que implica, necessariamente, pesquisa.

- Em segundo lugar, o professor deve produzir textos científicos próprios, "nos quais possa, de modo mais evidente e garantido, progredir no questionamento reconstrutivo, em termos teóricos e práticos", (Demo, 1997, p.41). De acordo com o autor, incentivar o professor a produzir textos próprios o induz a aprofundar-se em determinada temática, permitindo que saia da condição de mero leitor ou espectador para assumir a de contribuinte eficaz na (re)construção do conhecimento.

- Em terceiro lugar, é indispensável que o professor reconstrua permanentemente seu material didático. Além do material didático comum, por ventura existente na escola, o professor precisa dispor do seu próprio material. Para Demo (1997, p.45), "a finalidade específica de todo material didático é abrir a cabeça, provocar a criatividade, mostrar pistas em termos de argumentação e raciocínio, instigar ao questionamento e à reconstrução". Assim, é importante que o professor evite se tornar um usuário apenas de material didático alheio, decaindo na condição de mero porta-voz, pois "a maneira mais segura de evitar esta decadência, é produzir material próprio. Nesse processo, está implicada a necessidade de constante pesquisa, de con- traleitura sistemática, de acompanhamento de perto dos avanços científicos e didáticos na área", além da participação em seminários e eventos pertinentes a sua área de atuação profissional.

- Em quarto lugar, a educação pela pesquisa se evidencia nas inovações didáticas que o professor assume e sempre renova com vistas ao aproveitamento escolar. Demo sugere que tais mudanças devem perseguir os seguintes objetivos:

1. alcançar nítida qualidade formal, o que significa privilegiar o questionamento reconstrutivo, lutando contra a aula copiada, a postura passiva do aluno, a avaliação bancária. Em vez disso, o professor deve favorecer a formulação própria, alimentada na pesquisa.

2. fomentar a qualidade política, o que significa privilegiar a emergência do sujeito por meio do questionamento reconstrutivo. Aqui, o grande desafio é motivar a emancipação do aluno, trabalhando no sentido de alterar sua condição de objeto para sujeito, 'encontrando na instrumentação do conhecimento a alavanca principal para intervir, em contexto ético e solidário' (p.47).

- Em quinto lugar, a educação pela pesquisa supõe um processo de permanente recuperação da competência do professor, pois para ter capacidade inovadora o profissional da educação precisa constantemente refazer-se. Nesse sentido, é importante reivindicar do poder público a garantia de apoios indispensáveis ao cultivo da competência do professor.

Apesar de Demo (1991), ao referir-se a pesquisa no espaço educativo, restringi-la ao ambiente da escola e da atuação do professor de educação básica, não considera que a pesquisa, como princípio educativo, se esgote nesse horizonte. Esclarece o autor que justamente por entender que a pesquisa deve perpassar todo o processo formativo do aluno é que, em um primeiro momento, a situa na educação básica, lugar de onde deve emergir. Com relação à universidade, o autor pensa que uma visão alternativa de pesquisa, sem unilateralizar a face científica da pesquisa, "seria fermento apto a recolocar a universidade no caminho das esperanças sociais nela depositadas" (Demo, 1991, p.46). 
Na mesma linha do pensamento de Demo, Masetto (2003) ao discutir técnicas para o desenvolvimento da aprendizagem, considera que o ensino com pesquisa é uma estratégia fundamental para a melhoria da qualidade do ensino de graduação, pois é "a pesquisa se iniciando já na formação dos profissionais contemporâneos". Mas alerta que não é suficiente o professor "mandar o aluno fazer pesquisa", ao contrário, "será necessário orientar como se faz uma pesquisa e acompanhar sua realização". No seu entender, para o professor obter êxito com essa estratégia necessita seguir várias etapas, a saber:

- criar motivação para que os alunos participem da atividade, discutindo com eles no que consiste a pesquisa, sua validade, sua importância no processo de ensino-aprendizagem e como se relaciona com a aprendizagem que está sendo desenvolvida na disciplina ora cursada;

- discutir os critérios para a escolha do assunto ou da situação a ser pesquisada, lembrando que a pesquisa pode ser bibliográfica, de campo, ou incluir ambos os aspectos;

- discutir com os alunos a melhor forma de desenvolver o trabalho, se em grupos, ficando cada um com um aspecto do tema, ou individualmente, com cada aluno trabaIhando um tema próprio;

- apresentar e discutir com os alunos o que vem a ser um plano de pesquisa, seus elementos e sua organização;

- comunicar os resultados a todos os alunos e discuti-los em seguida (Masetto, 2003, p. 103).

Fica evidenciado o papel significativo que o professor desempenha no processo do ensino com pesquisa. Nesse processo, o docente transcende a posição de instrutor e passa a ser um orientador e parceiro na formação do educando e na produção do conhecimento. Por isso, Masetto (2003) alerta que dificilmente o aluno incluirá a investigação em seu processo de aprendizagem se o professor também não o fizer, isto é, se o professor não aprender também ele a atualizar e/ou renovar seus conhecimentos por meio de pesquisas, de leituras, de reflexões pessoais, de participação em eventos científicos, dentre outros.

Em estudos que exploram a relação ensino e pesquisa, Cunha $(1996$; 1997) formulou um quadro comparativo entre os paradigmas de ensino em que contrapõe as características do ensino como "reprodução do conhecimento" e do ensino como "produção do conhecimento". Em sua análise, a autora apresenta alguns pressupostos que considera essenciais para caracterizar um ensino com pesquisa, provocando a produção do conhecimento. Na sua concepção o ensino como produção do conhecimento:

- enfoca o conhecimento com base na localização histórica de sua produção e entende-o como provisório e relativo;

- valoriza a ação reflexiva e a disciplina tomada como a capacidade de estudar, refletir e sistematizar o conhecimento;

- privilegia a intervenção no conhecimento socialmente acumulado;

- estimula a análise, a capacidade do compor e recompor dados, informações, argumentos e ideias;

- valoriza a ação, a reflexão crítica, a curiosidade, o questionamento exigente, a inquietação e a incerteza, características do sujeito cognoscente;

- valoriza o pensamento divergente, parte da inquietação e/ou provoca incerteza;

- percebe o conhecimento de forma interdisciplinar, propondo pontes de relação entre eles e atribuindo significados próprios aos conteúdos, em conformidade com os objetivos acadêmicos;

- valoriza a qualidade dos encontros com os alunos e deixa a estes tempo disponível para o estudo sistemático e a investigação orientada (p.120).

Cunha concebe a pesquisa como atividade inerente ao ser humano, um modo de apreender o mundo, acessível a todos e a qualquer nível de ensino, guardadas as devidas proporções:

- entende a pesquisa como um instrumento de ensino e a extensão como ponto de partida e de chegada da apreensão da realidade;

- requer um professor inteligente e responsável, capaz de estimular a dúvida e orientar o estudo para a emancipação;

- entende o professor como mediador entre o conhecimento, a cultura e a condição de aprendiz do estudante (Cunha, 1997, p. 120). 
No entanto, a autora reconhece que o enfoque da reprodução do conhecimento tem influenciado profundamente o sistema científico e escolar brasileiro como reflexo de uma tradição positivista de ciência e a medida em que esta se perpetua contribui para a dissociação entre ensino e pesquisa. Analisando a questão por esta ótica, argumenta que

O ensino só será indissociável da pesquisa quando for construído um novo paradigma de ensinar e aprender que, ao emergir da crítica teórica ao positivismo, estabeleça um novo estatuto científico-social, com repercussão na organização de currículos e nos espaços acadêmicos de ensinar e aprender (Cunha, 1997, p.121).

As reflexões dos autores mencionados contribuem para entendermos melhor diferentes concepções didáticas, particularmente a didática comprometida com a aprendizagem do estudante enquanto resultante de um exercício contínuo de investigação. A importância de nomear esses estudos pode ser colocada em duas dimensões.

A primeira mostra que o questionamento ao paradigma em vigor está presente na literatura pedagógica contemporânea e que as pistas estão dadas para a construção de propostas didáticas alternativas.

A segunda refere-se ao fato que há significativas coincidências no conteúdo das propostas dos diferentes autores. Em todos eles está presente a intenção de estabelecer relações entre uma proposição pedagógica onde prepondera a reprodução do conhecimento cientificamente acumulado e uma outra que concebe o conhecimento como processo de produção, no qual a dúvida e a incerteza servem de estímulos ao aluno.

Além disso, dentre todos os autores destaca-se a crítica ao paradigma de ensino vigente e a defesa de um novo paradigma de ensinar e aprender, que aos poucos vai emergindo.

A razão desse estudo basear-se em autores da área de educação deve-se ao fato de a discussão em torno da concepção ensino com pesquisa no campo da Biblioteconomia e Ciência da Informação configurarem-se ainda de forma incipiente. De todo modo, em algumas publicações nacionais da área, percebemos um esforço em promover discussões em torno da proposição de um novo modelo de formação acadêmica e profissional, dando maior visibilidade às questões pedagógicas e apontando para a concepção de um projeto pedagógico que reforce a iniciativa investigativa no aluno (Transinformação, 2002; 2003; Rodrigues; Campello, 2004; Castro, 2007).

Diante disso, considera-se que os teóricos da educação propõem as bases da formação baseada no ensino com pesquisa e toma-se como referência seus estudos para investigar os docentes que atuam no ensino de Biblioteconomia e Ciência da Informação. O estudo desenvolvido buscou verificar, entre outros aspectos, se os docentes/pesquisadores estão procurando fazer rupturas com o paradigma tradicional de ensino e criando novas alternativas de aprendizagem.

\section{AS FALAS DOS PROFESSORES-PES- QUISADORES}

Como já explicitado na introdução do presente texto, os 19 professores sujeitos desta pesquisa são também pesquisadores que atuam no ensino de graduação em Biblioteconomia. Quinze têm formação de graduação em Biblioteconomia e apenas três são oriundos de outras áreas, especificamente arquitetura e engenharia, mas com experiências práticas no campo da informação. Somente um apresentou além da formação em Biblioteconomia, também outra formação, no caso, jornalismo. Dezesseis professores-pesquisadores cursaram doutorado em Ciência da Informação. Apenas três se titularam doutores em outras áreas, sendo que dois em comunicação e semiótica e um em letras. Antes de assumir a docência, atuaram como profissionais em bibliotecas, ou em variados tipos de instituições, serviços e unidades de informação. Com relação ao encaminhamento para a docência parece que foi mais por razões circunstanciais, pois apenas quatro professores manifestaram explicitamente o desejo de, após graduados, dedicarem-se à pesquisa e à docência. Desses, dois já haviam desenvolvido experiências no magistério do ensino fundamental e somente um declarou enfaticamente que "no último semestre da faculdade, eu já percebi que queria seguir a carreira docente" (PP19)3. Há um elemento comum,

\footnotetext{
3 À medida que as entrevistas eram realizadas, recebiam um número sequencial. Tal procedimento permitiu que as falas fossem codificadas de acordo com essa ordem. PP, significa professor-pesquisador.
} 
porém, entre todos. Independentemente dos caminhos que os levaram ao magistério, quase todos afirmaram que o doutorado foi decisivo para o refinamento da sua atuação docente.

Em um dos depoimentos o professor afirma que credita ao doutorado a sua preparação tanto para a pesquisa, como também para trabalhar com o ensino, explicando que "o que relaciona o doutorado à docência é que o doutorado ensina a gente a aprender sozinho, a estar sozinho, aprender a estruturar". 0 professor confessa que foi na pós-graduação que aprendeu a aprender (PP13). Um outro reconhece que sua experiência como professor-pesquisador evolviu muito entre o mestrado e o doutorado.

No mestrado aprendi a fazer pesquisa com con-
sistência, mas mais do que isso, aprendi a retor-
nar o crescimento científico adquirido para os
alunos em sala de aula. O doutorado me trou-
xe maturidade e me propiciou maior
flexibilização em relação à compreensão dos
objetos e fenômenos da área, que para mim é
essencial no que tange ao ensino-apren-
dizagem, principalmente, para o docente
(PP14).

Mas, na opinião de outro professor "há uma grande falha na pós-graduação, pois faltam disciplinas para o aluno aprender a ser professor na graduação". Para esse professor "as pessoas pensam que para lecionar é só aprender o conteúdo e não é só isso, na verdade é um processo que você vai construindo em sala de aula" (PP12). De certa forma, essas afirmações são confirmadas pelo depoimento de outro professor quando confessa que "somente o programa de mestrado me forneceu subsídios para atuar na carreira docente com algumas disciplinas de cunho didático-pedagógico, pois era da área de educação". Mas, quanto ao doutorado, realizado na área de letras, admite que não lhe forneceu "qualquer instrumental nesse sentido" (PP16).

Mesmo existindo opiniões divergentes, comentários como esses levam a crer que a interface de maior visibilidade para a graduação é a pós-graduação (stricto-sensu), tanto como local para a capacitação científica dos docentes, quanto para o aprimoramento dessa formação, de modo que eles desenvolvam competência para introduzir os alunos da graduação às formas básicas de investigação. Desse modo, poderia pressupor-se que o professor, após cursar um doutorado, ao retornar à sua unidade de ensino, socializa os novos conhecimentos adquiridos e a partir do domínio teórico e prático que passou a possuir é capaz de buscar novas explicações e compreensão mais abrangente dos fatos e atos que a realidade apresenta e/ou produz. Poderia, também, levar os alunos a fazerem aproximações com o real, interpretá-lo e, através de suas ações, como sujeitos históricos, transformá-lo atribuindo-lhe um novo sentido e novos significados.

No entanto, Cunha (1996a, p.32), em pesquisa que revela a preocupação de estudar a prática do professor universitário, considera que "o panorama usual dos cursos de graduação nega, quase sempre, a ideia do ensino com pesquisa". Em outro estudo que discute a relação entre o ensino e a pesquisa, Cunha (1997) argumenta que, apesar dos programas de pós-graduação perseguirem o objetivo de concretizar essa relação no ensino superior, na realidade, há um pressuposto equivocado nessas propostas, pois partem da suposição "de que a relação ensino e pesquisa se dá quando o professor estabiliza-se como investigador e traz para a sala de aula resultados dos seus estudos". A autora assegura que mesmo sendo esse um comportamento desejável, não garante a indissociabilidade entre ensino e pesquisa e muito menos o desenvolvimento de habilidades e atitudes científicas nos alunos. No seu entendimento, "quase sempre o ensino continua sendo de resultados e não raras vezes o professor- pesquisador tende a ser mais dogmático, defendendo a sua verdade, uma vez que ela é fruto do seu próprio processo de descoberta" (Cunha, 1997, p. 121).

Assim, podemos dizer que apesar da pós-graduação, em especial o doutorado, dar uma outra dimensão a ação docente, a articulação entre o ensino e a pesquisa não surge naturalmente, mas depende de um processo de construção. Depende, também, de um conjunto de circunstâncias que vão desde as políticas educacionais e científicas, passando pelas condições de recursos, equipamentos, espaço e tempo, chegando às diferentes concepções pedagógicas e epistemológicas dos professores-pesquisadores.

Nesse sentido, os depoimentos incluídos na categoria concepções de educação, ensino e aprendizagem, foram reveladores. 


\section{CONCEPÇÕES DE EDUCAÇÃO, ENSINO E APRENDIZAGEM}

De modo geral, os professores-pesquisadores veem a educação de forma mais ampla, chegando a afirmar que "[...] essa concepção vai além da formação profissional" (PP5), envolve "[...] não só a sala de aula, [mas] o contexto maior que o aluno tem", é "a formação dele como cidadão" (PP3). Outro explicita que quando fala em educação, de maneira geral, está "pensando em construção de algum tipo de ser humano" (PP7). Para outros, mais especificamente 3 professores, educação representa "uma visão de mundo", significando as referências que a pessoa traz consigo, ou seja, como se coloca no mundo (PP1 1, PP12, PP17). Essa ideia é complementada pelo depoimento de um outro professor-pesquisador que diz "para mim educação é processo contínuo de construção de conhecimento. Educação é a possibilidade de aprendizagem constante que o ser humano vivencia em sua vida. A educação é essencial para o homem 'ser' (PP14). Desse modo, as falas se coadunam com a visão de educação defendida por Damasceno (1999), e por nós adotada na pesquisa, de que a educação deve se constituir em uma práxis transformadora e crítica, aproximando-se, assim, dos preceitos do paradigma emergente. Mas, ao externar suas concepções de ensino e aprendizagem os professores-pesquisadores mostram que sentem dificuldades em pensar esses processos de modo integrado, conforme recomenda Masseto (2003). Dos 19 professores-pesquisadores entrevistados, apenas 5 explicitaram a ideia de que ensino e aprendizagem devem ser tratados como uma totalidade. Um dos professores confessa que para ele "é complicado dissociar [ensino e aprendizagem] porque para mim é troca" (PP7), no sentido de que professores e alunos ensinam e aprendem juntos.

Já um outro professor manifesta que para ele ensino e aprendizagem são uma coisa só, mas "para ser reflexo um do outro depende da forma como você ensina" e confessa que "na realidade, para mim o mais difícil é a avaliação desse processo. A avaliação é dolorosa porque quando você está avaliando não está avaliando só um conteúdo, mas também a sua capacidade de ensinar" (PP12).

Ao conceber a educação como um processo global de formação, um outro professor-pesquisador pensa que para esse processo se concretizar requer estratégias de ensino-aprendizagem, ou seja, demanda "ações que envolvem alunos e professores para aquisição de conhecimento já sistematizado e produção de novos conhecimentos". Desse modo, "ensino e aprendizagem são, pois, processos solidários, cujo resultado desejado é a autonomização crescente do aluno no processo de produção de conhecimento" (PP15).

Contudo, em outras falas percebe-se a distância colocada entre esses dois processos, refletindo a influência do paradigma newtoniano - cartesiano: "[...] o professor ensina, o aluno aprende. São dois mundos bem distintos" (PP4). Um outro depoimento considera que o ensino deve "propiciar condições para o indivíduo saber pensar e, também, saber criticar". Já a aprendizagem "está vinculada ao indivíduo e a sua condição de 'ser'. Por isso, a aprendizagem está relacionada ao processo de transformação do indivíduo [...]". Nessa fala fica claro que "não existem parâmetros/ normas para a aprendizagem, uma vez que ela é diferente para cada ser humano" (PP14).

Um outro professor considera que o ensino deve ser organizado com o objetivo de propiciar a aprendizagem. Para ele o ensino envolve "local, pessoas, conteúdos, recursos, etc.", enquanto que a aprendizagem é o "momento em que o indivíduo, em contato com novos conteúdos e situações, desenvolve seu conhecimento e habilidades a respeito de um assunto prático ou tema" (PP16).

Em outro depoimento, o professor confessa que nunca estudou formalmente esses conceitos, para ele "ninguém ensina, a pessoa aprende ela mesma, o aprendizado é interno à pessoa". Na sua concepção "o professor não ensina, você pode fazer uma seleção de leituras, dar um caminho para o aprendizado, mas quase tudo depende da própria pessoa" (PP13).

Já para um outro professor "o ensino é um processo de comunicação, onde aquele que está repassando tem que ter uma ação singela [...] de perceber como o outro pode aprender aquele conhecimento". Nessa visão, "a aprendizagem representa o quanto o outro pode aprender" (PP17). Em outra fala, o ensino é visto como "[...] uma verdade a ser transmitida", enquanto que a aprendizagem já é considerada um processo: "a aprendizagem supõe a negociação, a apropriação e, consequentemente, a 
transformação da informação em conhecimento". No entanto, o professor-pesquisador reconhece que "as práticas acadêmicas estão muito mais marcadas pelas relações de autoridade" (PP2).

Podemos dizer, com base nesses depoimentos, que os professores-pesquisadores são capazes de perceber que as práticas educacionais e a estruturação institucional da universidade estão ancoradas no paradigma tradicional (newtoniano-cartesiano). No entanto, o que não fica claro é até que ponto eles compreendem o quanto a simples aceitação desse fato fortalece ainda mais o paradigma vigente, pois se percebe uma certa acomodação à situação descrita, uma vez que nenhum esboço de resistência é revelado.

Foi externado, também, inquietação quanto ao maior conhecimento, por parte dos professorespesquisadores que atuam no ensino de Biblioteconomia, das metodologias de ensino. "[...] a gente precisava conhecer mais metodologia de ensino. [...]. Eu acho que com a metodologia de ensino você tem um ensino mais interativo, você consegue formular aquele conteúdo de uma forma que os alunos possam exercer mais praticamente $[. .]$.$" . No entanto, reconhece "[...]$ que falta também toda uma base infra-estrutural na universidade para que isso aconteça, isso também não depende só da intenção" (PP10).

Outro professor confessa que o início de sua atividade docente foi penoso, basicamente por duas razões: "falta de domínio amplo do campo de conhecimento e falta de experiência didática". Explica que "a pesquisa de pós-graduação foi essencial para sanar as lacunas relativas ao conhecimento. No entanto, como a pós-graduação não prevê formação didático-pedagógica, procurei sanar essa lacuna por meio de seminários, cursos e leituras". Na sua opinião, "a maioria dos docentes, embora tenha formação teórica suficiente, por força da pesquisa em pósgraduação e pós-doutoral, enfrenta dificuldades para desenvolver de forma satisfatória a atividade de docência". Conclui que, "após quase trinta anos de atividade docente, adquiri as competências e habilidades mínimas para ensinar", mas pensa, "que há uma contradição no ensino superior: exige-se que o docente faça pesquisa, mas não se exige que tenha formação pedagógica também permanente" (PP15).

Essas falas nos remetem à discussão sobre as competências básicas para o exercício da docência universitária o que, por sua vez nos leva a refletir sobre a estrutura organizativa do ensino superior que sempre "privilegiou o domínio de conhecimentos e experiências profissionais como únicos requisitos para a docência nos cursos superiores" (Masseto, 2003, p.1 1). Com relação à área de Biblioteconomia, pelo perfil anteriormente apresentado dos docentes, todos com experiências profissionais no campo da informação, a situação não é diferente. Mesmo com as novas determinações dos concursos públicos, nos últimos tempos as universidades passaram a requerer, além do bacharelado, cursos de especialização, mestrado e, principalmente, doutorado aos candidatos a professor. Observa-se que as exigências para se tornar docente continuam as mesmas, "pois se referem ao domínio de conteúdo em determinada matéria e experiência profissional" (Masseto, 2003, p.12). Contudo, pela inquietação externada nesses depoimentos, podemos deduzir que os professores começam a se preocupar de que seu papel de docente exige capacitação própria e específica, ou seja, competência pedagógica, pois ele é um educador.

Essa observação nos encaminha para a categoria práticas pedagógicas quando procurou-se detectar como os professores desenvolvem a sua prática pedagógica, ou seja, como descrevem o cotidiano da preparação e execução de seu ensino e o que apontam como dificuldades nesse exercício.

\section{Práticas pedagógicas}

depoimento dos professores-pesquisadores sobre como preparam e executam sua prática pedagógica, mostrou que a maioria 16 se preocupa com o planejamento dos conteúdos a serem ministrados. Alguns partem do plano de ensino da disciplina para visualizar suas aulas "[...] eu sempre incluo no plano de ensino [a] situação de ensino-aprendizagem pela pesquisa [...]" (PP3); "com base nos programas de ensino das disciplinas (que são atualizados periodicamente), planejo a distribuição dos conteúdos e atividades ao longo de cada semestre" (PP15); "os conteúdos são planejados de forma a contemplar a súmula da disciplina e incorporar elementos atuais que, por vezes, não poderiam estar na súmula" (PP18). Explica, ainda, que planeja "os conteúdos que serão ministrados em cada aula no início do semestre, mas isso não significa que não possa haver adaptações/ mudanças no decorrer dele" (PP18). Outro professor 
informa que "o plano de ensino para essa disciplina é baseado em leituras e discussão de textos e em mapas conceituais. Seleciono textos que vão embasar os diferentes tópicos e também solicito aos alunos que apresentem textos do seu interesse [...]" (PP1).

Outro professor-pesquisador revela a preocupação com a organização da disciplina quando diz que "eu me vejo como uma organizadora, quando eu ensino uma disciplina quem mais aprende sou eu mesma. Eu seleciono, eu sintetizo, eu organizo, realmente sou muito minuciosa, muito organizada e muito estruturada" (PP13).

Alguns declaram que partem do plano de ensino, mas se preocupam em considerar os interesses e conhecimentos prévios dos alunos para delimitar o papel que a disciplina terá no processo de ensino-aprendizagem, "de acordo com o programa e com o conhecimento prévio dos alunos e seus interesses. A base tem que ser o que o aluno já sabe. $O$ interesse do aluno deve ser estimulado para poder haver aprendizagem" (PP9).

Por fim, alguns professores-pesquisadores manifestam a preocupação em, primeiramente, ressaltar o(s) conteúdo(s) da(s) disciplina(s) para os alunos, visando sua aplicação:

Eu tenho uma certa visão que de cara você tem que trabalhar a questão do conteúdo, estar bem presente a questão do conteúdo, a questão da forma como você coloca isso e também a questão de você fazer o movimento, que é a "práxis". Então, minhas aulas sempre se colocam dessa forma: de sempre apresentar o conteúdo para os alunos e fazer com que eles façam um movimento de aplicação com esse conteúdo (PP4).

Pode-se perceber que a ideia de planejamento varia em cada professor e a forma como o elaboram e de como dele se utilizam também. Mas, não podemos ignorar que há um arcabouço do curso ou da disciplina já apreendido por eles que nem sempre é consciente. Na maioria das vezes a prática com determinada disciplina já definiu os constructos de sua forma de pensar, nesse caso os planos de ensinos têm pouco significado. Por outro lado, não parece haver relação direta entre o êxito do professor e um plano de ensino explicitado corretamente.
As afirmações anteriores levam a crer que a natureza do conteúdo da disciplina tem a ver com a metodologia adotada, mas não devemos esquecer que a visão que o professor tem da produção do conhecimento é também importante no delineamento do método, um professor declara que "durante a atividade sempre enfatizo que o conhecimento é cumulativo, vai se formando em camadas, mas que para haver avanços na formação é necessário aprender a fazer relacionamentos" (PP1, grifo nosso), o que ainda reflete uma visão fragmentada de construção do conhecimento.

Os seminários, leitura e discussão de textos, atividades práticas e de laboratórios, aulas expositivas, foram os recursos mais usados nos procedimentos didáticos cotidianos. Isso pode demonstrar o esforço dos professores na busca de uma melhor articulação entre a teoria e a prática. Um professor que usa a metodologia de mapas conceituais explica que "a partir da discussão de um texto, os alunos se reúnem em grupo e vão elaborar o mapa conceitual" (PP1). Outro que trabalha com bibliometria, fontes e redes especializadas em informação menciona que usa muito "a modalidade de seminários" (PP4). Outro depoimento declara que para as disciplinas mais teóricas "mesclo aulas expositivo-dialogadas [...] com atividades práticas e de laboratório". Explica que "na medida do possível, busco dividir o tempo total de cada encontro pela metade, a fim de contemplar esses dois aspectos" e ainda acrescenta que "utilizo também as TIC como mediação, na forma de ferramentas como ambientes de aprendizagem, blogs, e-mail etc." (PP18). Já outro professor-pesquisador que lida com os fundamentos da área de Biblioteconomia considera que essa é uma disciplina muito conceitual, por isso "às vezes eu dou aulas expositivas e outras vezes eu passo pesquisa". No último caso, trabalha em forma de seminário e ressalta que "na disciplina de fundamentos eu faço uma articulação de todos esses conceitos que envolvem a Biblioteconomia e a Ciência da Informação, pois elas ao mesmo tempo que são muito próximas, também tem suas particularidades" (PP12). Um outro professor que atua no campo das tecnologias da informação declara que desenvolve esses conteúdos em termos práticos e teóricos.

Sabe-se, contudo, que o simples fato do professor encaminhar trabalhos em grupo ou se utilizar de diferentes recursos técnicos e didáticos não garantem a 
realização de uma proposta pedagógica inovadora. Não se deve esquecer que na proposta do paradigma emergente o conhecimento é processo, portanto não é absoluto nem acabado (Santos, 2002b). Nesse processo professores e alunos devem estar engajados em movimentos interativos de ensino-aprendizagem. $\bigcirc$ que se percebeu é que, de modo geral, os professores encontram dificuldades estruturais para o uso de uma metodologia mais criativa

Tentei uma experiência de fazê-los publicar seus resultados de pesquisa e de realizar a crítica dos trabalhos dos outros grupos. A experiência ofereceu bons resultados, mas mostrou carências de infraestrutura operacional. O trabalho do professor aumenta muito e nem sempre conseguimos responder convenientemente (PP2).

Contudo, alguns manifestam o esforço no sentido de que a aula seja um espaço coletivo e que as formas de agir do professor e dos alunos levem a essa mobilização. Em uma fala é expressa a preocupação com a discussão coletiva dos conceitos trabalhados na disciplina. $O$ professor-pesquisador informa que cada aula ou atividade "se articula em torno de teorias, conceitos e sua operacionalização, se for o caso". Nesse sentido, "cada unidade contempla a realização de exposição de conceitos pelo docente, a discussão coletiva desses conceitos, exercícios e seminários" (PP15).

Quanto às dificuldades enfrentadas pelos professores-pesquisadores no seu cotidiano pedagógico, três pontos principais foram enunciados: estrutura do ensino, condições de trabalho e carência de formação pedagógica.

A estrutura do ensino diz respeito ao modelo de ensino que a legislação contemporânea determina, o qual aprofunda a desigualdade pelos resultados finais do processo escolar. Além disso, os currículos extremamente estratificados não dão conta de trabalhar o conhecimento nas complexas relações sociais do mundo de hoje. Um professor atesta que "[...] a maior dificuldade é lidar com níveis diferentes de conhecimento e interesse dos alunos [...]" (PP9). Outro professor coloca essa questão em vários níveis de problemas, o primeiro deles "[...] eu diria que é um problema social, os nossos alunos vêm com um capital cultural muito baixo". Mais um problema que esse professor detecta é com relação à postura dos alunos, "[...] eles vêm de uma postura muito adolescente, muito irresponsável, de não chegarem na hora, de não entregarem os trabalhos no prazo [...]" (PP10). Um outro professor, de forma indireta, também se refere a esse ponto "[...] de modo geral eu procuro infundir nos alunos a responsabilidade profissional porque tem que ter e chamo bem a atenção nesse sentido". Outra fala ressalta a perda de motivação do aluno durante o percurso escolar: "eu não sei porque no transcorrer do curso os alunos vão perdendo a motivação". Atribui essa perda de motivação ao fato de que "há uma diversidade muito grande de professores, com conceitos e técnicas de ensino diferentes" (PP12).

Outro problema apontado com relação ao modelo de ensino adotado é quanto à capacidade dos alunos se comunicarem, tanto na forma oral, como na escrita. Percebem-se dificuldades na argumentação, organização, discussão e registro das ideias. Um professor confessa que "[...] eu exijo muito a questão da comunicação, falar e escrever. E aí está uma dificuldade". O professor pondera que essa dificuldade não vem "só da universidade, mas acaba sendo um problema que é trazido para a universidade e a gente tem que solucionar" (PP6). Para outro professor a dificuldade está ligada "ao tipo de aluno que a gente recebe, falta à eles um arcabouço cultural, você tem que fundamentar o tempo todo é uma dificuldade grande porque eles não têm hábito de estudo, não têm hábito de leitura" (PP17). As condições de trabalho também foram apontadas como um fator de dificuldades para os professores. Eles referem-se principalmente à falta de infraestrutura adequada para desenvolver as atividades de ensino. Um depoimento reconhece que dificilmente a prática ocorre da forma como é idealizada e que, "por vezes, equipamentos não funcionam, alunos não se sentem motivados ou não têm tempo devido, há uma sobrecarga de atividades, não consigo tempo suficiente para as leituras que gostaria de fazer" (PP18). Já, para outro professor a principal dificuldade, sem dúvida, é a questão da infraestrutura, mas explica que não se refere ao espaço físico e sim ao maior número de pessoal de apoio. "Como nós temos diversas obrigações, muitas vezes nos falta um respaldo de recursos humanos para nos apoiar. Então, tudo nós temos que providenciar" (PP3). Outro depoimento revela a mesma situação "com o acúmulo de funções e de trabalho o tempo necessário para estudo e leituras para atualização ficaram bastan- 
te reduzidos, o que prejudica o ensino e a própria condução da pesquisa" (PP16). Pelos depoimentos destacados podemos dizer, portanto que esses obstáculos interferem na qualidade do ensino.

Os aspectos referentes à carência de formação pedagógica foram bastante salientados pelos docentes. Vários se referiram a essa questão o que demonstra que se preocupam com uma preparação pedagógica que conduza a uma apreensão bem sucedida das formas de ensino e de construção desse ensino.

Um professor declara que é bastante crítico em relação a sua prática pedagógica e confessa que "ainda apresento insegurança na condução da avaliação dos alunos". Quanto à didática usada para trabalhar o conteúdo em sala de aula "acho que precisa ser atualizada mediante as novas possibilidades de recursos interativos como blog, EAD etc." (PP16).

Um outro professor declara seu pouco conhecimento a respeito das teorias de ensino e confessa que "[...] vou tateando ..., mas acho que estou longe de estar capacitado para conseguir transmitir melhor os conteúdos que eu tenho que transmitir". No seu entendimento, o trabalho do professor é muito solitário e sente falta do diálogo com outros colegas: "[...] eu acho que ainda é um trabalho muito solitário, existe muito pouca troca, [de perguntar ao outro] o que você está fazendo, como eu posso complementar seu conteúdo" (PP10). Outra fala explicita essa mesma preocupação quando afirma que "a organização administrativa da universidade leva a pouca comunicação entre os professores, o que resulta em pouca discussão dos problemas" (PP12). Estas falas mostram que os docentes do ensino superior não têm o hábito de refletir coletivamente sobre o que fazem, ao contrário, estão "acostumados a processos de planejamento, execução e avaliação das atividades (tanto de pesquisa, quanto de ensino) de forma individual, individualista e solitária" (Pimenta et al., 2002, p. 142). Portanto, superar essa forma de atuação se constitui em um desafio, pois requer intencionalidade, envolvimento e disponibilidade para mudanças além de um espaço institucional favorável.

Por fim, dificuldades de outras naturezas foram também apontadas pelos docentes. Entre elas apareceram aspectos referentes à metodologia de ensino usada, "o que percebo é que alguns alunos se cansam de fazer mapas conceituais e se queixam com a quantidade de leituras a fazer. De modo geral, pedem trabalhos mais práticos que não demandem muita reflexão". O próprio professor discute sobre essa objeção a reflexão e considera que "isso é a síndrome da Biblioteconomia em geral" e considera "a relação teoria/prática no ensino da área muito complicada". Pensa que "a teoria deve se alimentar da prática e vice-versa", mas confessa que "é muito difícil realizar esse processo" (PP1).

Na verdade, essa dificuldade não é percebida somente nas áreas de Biblioteconomia e Ciência da Informação. Cunha (1998, p.81) explica que:

Em geral, no ensino tradicional, teoria e prática são geralmente vistos como momentos distintos na apropriação do conhecimento. Embora esta separação seja mais formal do que real, ela existe vinculada à ideia de divisão de trabatho presente na escola.

A autora busca em Lucarelli (1994) os fundamentos para a compreensão dessa realidade que, por sua vez, ressalta o fato de existirem diferentes formas de conceber teoria e prática e a relação que pode se estabelecer entre elas. Também critica o fato de que, em geral, "teoria e prática são entendidas como tarefas separadas e até excludentes, desenvolvidas uma a margem da outra".

A tendência das nossas instituições de ensino, inclusive a universidade, é a de comprovar as teorias anteriormente estudadas através da prática, o que gera um distanciamento entre uma e outra, pois em vez da prática alimentar a teoria e lhe proporcionar os elementos para a reflexão, pressupõe-se que a competência prática começa onde termina o conhecimento teórico. Mesmo nas áreas de Biblioteconomia e Ciência da Informação, consideradas campos de aplicabilidade, a relação da teoria com a prática não se constitui em um processo dialético. Via de regra, os estudantes queixam-se de que os cursos não preparam para a realidade dos problemas que irão enfrentar depois de formados.

Outra dificuldade apontada diz respeito à publicação das experiências didáticas desenvolvidas pelos professores. Um professor alega que "[...] tem muita coisa que você faz em sala de aula que é muito boa, mas que você não consegue socializar num âmbito maior. Daí muito material de sala de aula importante se perde $[. . .]^{\prime \prime}$. No entendimento desse 
professor "[...] a grande dificuldade nossa realmente é dar vazão a essas experiências" e alega que a área tem "ótimos eventos de pesquisa, mas não temos eventos de formação" (PP3).

Pelos depoimentos apresentados, podemos dizer que, de modo geral, os professores acreditam que a função docente seja própria e bem caracterizada. Dos entrevistados nenhum verbalizou formas de ensino não diretivas. Ao contrário, todos eles se percebem como articuladores do processo de ensino-aprendizagem que ocorre nos alunos. Por isso, alguns se dizem exigentes e valorizam esta característica em si "[...] eu cobro horário, cobro formato de trabalho, cobro uma postura [...]" (PP10).

Mas, a compreensão de que é necessário se construir continuamente como professor é fundamental para o avançar no processo da docência e do desenvolvimento de habilidades pedagógicas. É importante, também, desenvolver práticas que permitam vivenciar diferentes atividades processadas coletivamente. Além disso, é interessante lembrar que o paradigma emergente prevê a resignificação dos papéis do professor e do aluno: de transmissor de informações, para o qual foi formado, o professor passa a ser mediador pedagógico junto aos alunos, desenvolvendo um trabalho em equipe onde professor e aluno são os agentes/parceiros e co-responsáveis nas ações de aprendizagem. As práticas pedagógicas aqui estudadas não permitem perceber uma ruptura com o paradigma tradicional de ensino, mas é bom advertir que tanto os docentes, como os alunos, ainda são fortemente impregnados pelos postulados do paradigma cartesiano-newtoniano devido aos seus métodos já reconhecidos para a formulação e apreensão do conhecimento. Desse modo, a proposta de educação e ensino que emerge com o novo paradigma provavelmente será paulatinamente assimilada.

Por outro lado, a própria universidade terá que sofrer uma re-estruturação em sua organização acadêmica e para isso políticas públicas que estabeleçam princípios para nortear as atividades de graduação, diretrizes, metas e parâmetros para o seu desenvolvimento concreto, serão necessárias. Atualmente, apesar de representar o maior contingente quantitativo, em termos de alunos e de cursos, o ensino de graduação nas universidades brasileiras tem se ressentido da falta de programas governamentais de apoio e fomento às suas iniciativas e necessidades.
De todo modo, como se trabalhou com um grupo especial de professores, que além das atividades de ensino dedicam-se também à pesquisa, é de se esperar que tenham desenvolvido as habilidades inerentes a uma atitude inquieta, investigativa, reflexiva e crítica, associando-as ao exercício da docência. Resta saber se esses mecanismos estão inseridos na proposta de ensino que desenvolvem, isto é, se a pesquisa faz parte do seu cotidiano pedagógico. Essa observação nos encaminha a terceira categoria de análise vinculação pesquisa-ensino.

\section{Vinculação pesquisa-ensino}

Nesta categoria procuramos verificar se existe alguma ligação entre a pesquisa que os professores realizam e os conteúdos das disciplinas que ministram na graduação, com a intenção de descobrir se percebem a pesquisa como uma necessidade intrínseca ao ensino.

Dos 19 professores-pesquisadores entrevistados 16 declararam que procuram formular seus projetos de pesquisa vinculados às disciplinas que ministram. Um professor afirma que "[...] sempre fiz meus projetos vinculados às disciplinas que ministro" (PP5). Outro considera que sua pesquisa está totalmente ligada ao ensino que exerce, pois "da pesquisa nasceu, por exemplo, uma das novas optativas oferecidas na graduação" (PP2). Mais um faz essa mesma ligação porque estuda e pesquisa os fundamentos das áreas de Biblioteconomia e Ciência da Informação e "cada novidade que surge nas pesquisas que eu faço, eu trago para a sala de aula" (PP12). Outro explica que "na medida do possível eu sempre estabeleço um vínculo entre o que pesquiso e o que ministro em sala de aula" (PP14). Já em outra fala fica evidenciada a ligação direta entre o campo de pesquisa, as disciplinas ministradas e a produção científica do professor: "minha área de pesquisa é organização da informação. As disciplinas que ministro estão vinculadas a esse campo. Minha produção científica está focada, basicamente, nessa área" (PP15). Complementa, chamando a atenção para o fato de que na sua instituição "não há atividade de ensino desvinculada da pesquisa" e explica que "essa exigência tem sido fundamental para garantir que os alunos também acompanhem a dinâmica científica da área em que atuamos". No entanto, na sua opinião, "deve-se ter clareza sobre as especificidades de cada atividade" e faz a seguinte distinção: 
A atividade docente requer o desenvolvimento permanente de projetos de pesquisa própria para orientação de projetos de alunos de graduação e de pós-graduação. Não se pode, desse modo, confundir pesquisa de aluno (para formação) e pesquisa de docente. Esta última é pesquisa sênior, cujo escopo requer exploração teórica e metodológica distinta das pesquisas realizadas por discentes (PP15).

Contudo, alguns professores confessam que vêm uma relação apenas indireta entre seu tema de pesquisa e o(s) conteúdo(s) da(s) disciplina(s) que trabalham na graduação. "Não diretamente. Na realidade como minha pesquisa atual é sobre as ofertas de emprego para o bibliotecário disponíveis na Internet, costumo trazer para os alunos as novas possibilidades de atuação na área". Porém, esse professor considera que "geralmente o aluno que trabalha comigo em iniciação científica escolhe trabalhar comigo porque já ouviu falar do tema em minhas aulas o que, de certa forma, o desperta para a pesquisa". Esse mesmo professor ao explicitar o conceito que tem de pesquisa afirma que "considero fundamental que o professor desenvolva pesquisa porque, mesmo que esta não esteja diretamente ligada à disciplina que está ministrando, proporciona outras formas de ver e questionar a realidade" (PP1). Outro professor imagina que seu objeto de estudo" tem a ver com o que eu ensino na graduação no sentido de que eu trabalho muito com fontes eletrônicas de informação". Explica que seu objeto de estudo "são os periódicos eletrônicos, o sistema de informação do Portal CAPES, biblioteca digital", mas que a questão de pesquisa não tem a ver com o que trabalha na graduação estritamente. Reconhece, no entanto, que "quando eu vou falar de serviço de informação, de usuário, de atendimento à demanda, da questão da informação, da entrevista de referência, tem a ver com o usuário do Portal CAPES" (PP13).

Já outro professor confessa que ao formular seu projeto de pesquisa não teve a preocupação de relacionar com o que ensina na graduação, mas pensa que "tem uma ligação porque meu projeto atual tem a ver, de uma certa forma, com tecnologia da informação que é minha área de formação". Na opinião desse professor "a ponte entre o ensino de graduação e a pesquisa é mais distante, ela é mais próxima com o ensino de pós-graduação, aí eu acho que tem disciplinas que foram resultado dessa pesquisa [...]" (PP10). Ainda, um outro professor manifesta opinião semelhante ao considerar que sua pesquisa tem uma relação apenas indireta com sua(s) disciplina(s) da graduação e que "relaciona-se mais diretamente com disciplinas da pós" (PP9). Na mesma linha desses dois últimos depoimentos, um outro professor revela que sua pesquisa não tem vinculação com as disciplinas que ministra na graduação e confessa que "minha concepção de pesquisa não é a da pesquisa como prática pedagógica (ou pesquisa escolar), mas a da pesquisa científica" e por isso acredita que não é possível a vinculação da pesquisa ao ensino.

Os depoimentos destacados revelam que há um esforço por parte de alguns professores em relacionar a pesquisa que desenvolvem com sua matéria de ensino, mas parece que esse esforço é mais pessoal do que consequência de uma política institucional. Dos entrevistados apenas três declararam haver uma política institucional na sua unidade de ensino voltada para o ensino e a pesquisa na graduação. Isso demonstra que recai no professor a tomada de decisão sobre o seu fazer docente do que na instituição, ainda que se tenha que reconhecer que o ambiente institucional influencie sobremaneira no projeto individual do professor. A ausência de projetos institucionais permite que o projeto individual do professor tenha mais força. Se isto, por um lado, pode ser positivo, na medida em que represente liberdade e autonomia para o docente, por outro pode ser nefasto, pois pode significar uma total dependência da individualidade do professor e de seu grau de compromisso e competência.

Examinada a existência de vinculação entre os conteúdos das disciplinas que os professorespesquisadores ministram na graduação e a pesquisa que desenvolvem, passamos a averiguar se aqueles que confirmaram fazer essa ligação também trabalham a pesquisa como um princípio pedagógico, isto é, se exercitam a prática do ensino com pesquisa. Essa preocupação nos direciona para a categoria pesquisa como procedimento pedagógico.

\section{Pesquisa como procedimento pedagógico}

exercício do ensino com pesquisa pode ser percebido em alguns depoimentos, na verdade, observou-se a pesquisa como algo que permeia a 
prática pedagógica dos professores-pesquisadores. $\mathrm{Na}$ busca da compreensão de conceitos que se dão, por exemplo, nas disciplinas que tratam de indexação e linguagens documentárias, alguns professores tentam levar seus alunos a construírem uma atitude de pesquisa o que significa, segundo Demo (1997, p.2) "[...] promover o processo de pesquisa no aluno".

Outro professor (PP15) que também trabalha com linguagens documentárias afirma que "não creio que se possa pensar o processo de formação sem pesquisa". Ressalta que já afirmou anteriormente na entrevista que "a pesquisa visa à produção de conhecimento. Portanto, o ensino de graduação sem pesquisa, será mera reprodução". Segue seu depoimento, detalhando como desenvolve a atividade de pesquisa nas disciplinas que ministra:

Primeiro: a construção do projeto exige a identificação de um problema e conjecturas sobre os possíveis modos de dar solução ao problema. A construção do projeto e seu desenvolvimento exigem leitura e reflexão. A leitura de textos teóricos e metodológicos está vinculada ao desenvolvimento do projeto. Exige, portanto a apropriação do que está sendo lido e sua expressão com autonomia. A execução do projeto será bem sucedida se o aluno aplicar criativamente o que leu, ou seja, se re-elaborar o conhecimento disponível em textos (PP15).

Para esse professor, em síntese:

\begin{abstract}
Os trabalhos realizados na graduação exigem a mobilização de conceitos, teorias, métodos e técnicas. Nesse processo, cabe ao professor indicar as referências teóricas e as opções metodológicas que poderão sustentar o desenvolvimento do projeto e, simultaneamente, problematizar os caminhos apontados pelos discentes. Desse modo, acredito que apenas aqueles que realizam pesquisas, de forma sistemática e permanente, podem ser bons orientadores de pesquisa discente (PP15).
\end{abstract}

No entanto, em outro depoimento de um professor que pesquisa integração de linguagens, compatibilização de linguagens, web semântica e integração de redes de informação, fica enunciada a dificuldade em articular a pesquisa que desenvolve ao ensino que ministra na graduação, apesar de reconhecer que quanto à natureza desse conhecimento "a pesquisa deve estar integrada/relacionada ao ensino de graduação" (PP17).

Já outro professor (PP2) consegue explorar e aproveitar sua atividade de pesquisa em uma das disciplinas que ministra. "Na disciplina que mais se relaciona à minha pesquisa, os alunos experimentam processos que trabalham os conceitos e sua aplicação $[\ldots]^{\prime \prime}$ e explica como desenvolve essa metodologia.

Partimos de uma explicação geral sobre o conteúdo de uma disciplina e a forma de trabalho a ser adotada. Exploramos a cada aula uma série de conceitos e, em seguida, solicitamos aos alunos que exercitem a apropriação de conceitos. De exercícios realizados, primeiramente em classe, eles são solicitados a procurar novas fontes para resolver os problemas colocados ampliando as bases de conhecimento inicialmente utilizadas. Novos conceitos são introduzidos e o processo se desenvolve progressivamente até a apresentação de um resultado ou uma aproximação (PP2).

Outro professor, apesar de manifestar a convicção de que faz ensino com pesquisa, é de opinião que "a atividade investigativa em sala de aula, tem que ser feita com alguns parâmetros, porque a disciplina é limitada, em tempo, em proposta" (PP3).

Ainda com relação a essa questão do estabelecimento de parâmetros para a pesquisa no ensino de graduação, encontrou-se em outro depoimento a mesma preocupação. $\bigcirc$ professor reconhece que a utilização da pesquisa como instrumento de aprendizagem "é um dos princípios da competência informacional". Porém,

A pesquisa relacionada ao ensino de graduação, na forma como o ensino é organizado tradicionalmente (em disciplinas articuladas, mas que enfocam diferentes aspectos de um dado fenômeno ou conhecimento, com carga horária específica e reduzida tendo em vista o desenvolvimento de uma pesquisa) não permite a meu ver a realização da pesquisa científica aquela que faz avançar o conhecimento acumulado e registrado. Mas pesquisas como revisão da literatura, experimentações, pequenos levantamentos (surveys), que também são 
práticas válidas para aprendizagem e em que estão apoiadas de um ensino mais interativo (PP16).

Por isso revela que seu trabalho com a pesquisa no ensino de graduação se pauta pela preocupação em não apresentar respostas prontas aos alunos. Desta forma, costuma solicitar que eles "procurem na literatura, façam visitas e entrevistas em locais e com pessoas que possam trazer contribuições e explicitar sua prática a respeito do assunto, levando dados resultantes de pesquisas para serem discutidos e analisados" (PP16).

No depoimento desses professores-pesquisadores percebemos o esforço em introduzir nas disciplinas que ministram pequenos processos de investigação. A realização de trabalhos de pesquisa, ainda que incipientes, na medida em que não ultrapassam a descrição da realidade ou o levantamento bibliográfico, mostram a preocupação em buscar alternativas que superem a pedagogia tradicional de ensino. Podemos dizer, então, que os primeiros passos recomendados por Demo (1997) no sentido de estimular a pesquisa no aluno: procurar material bibliográfico, motivar a fazer interpretações próprias, reconstruir o conhecimento como maneira própria de aprender, são dados por esses professores (grifo nosso).

Finalmente, pelos depoimentos apresentados podemos dizer que a maioria dos professores está consciente com relação à importância da articulação das suas atividades de ensino e pesquisa. Conforme se ressaltou anteriormente, dos 19 professores-pesquisadores entrevistados, 16 procuram vincular suas ações de pesquisa às disciplinas que ministram na graduação para melhor desenvolver seu trabalho pedagógico.

\section{CONSIDERAÇÕES FINAIS}

A análise dos depoimentos colhidos nessa pesquisa foi de muito valor para perceber como as experiências de ensino com pesquisa estão acontecendo nas áreas de Biblioteconomia e Ciência da Informação e se estas evidências estão caracterizando uma transição do paradigma dominante para o emergente.

Ao relatarem como desenvolvem sua prática pedagógica alguns dos professores-pesquisadores deixam transparecer que estão muito próximos da concepção do conhecimento como construção, detectam anomalias, percebem que algo não vai bem, mas parece que ainda não têm muito claro o processo de mudança. Questionam o paradigma dominante, mas até o momento não mudaram de perspectiva. Outros parecem que já se encontram mais distantes, pois suas propostas de trabalho apresentam-se apoiadas num conceito de conhecimento e ensino do paradigma positivista. Consideradas as tendências, temos, então, aqueles que percebem o conhecimento e o ensino como construção e outros que o consideram como transmissão de um saber pronto. Isso resulta no seguinte quadro: ao lado de propostas de trabalho criativas, se apresentam outras, residuais talvez, apoiadas em modelos tradicionais de ensino.

Podemos dizer que os professores-pesquisadores procuram melhorar a sua ação docente, mas ainda sob um paradigma pedagógico que, a priori, se apoia em um conceito de aprendizagem sustentado pela concepção de que primeiro o aluno deve adquirir conhecimentos para depois aplicá-los na prática e em situações específicas.

O envolvimento e a desmitificação da pesquisa nas experiências relatadas revelam o esforço desses professores em procurar adotar novas práticas ou novas posturas no processo de ensino-aprendizagem. Contudo, as experiências observadas, por si só, não representam uma ruptura com a reprodução do conhecimento. Pelas falas dos professores-pesquisadores pode-se observar que os alunos sentem dificuldade em realizar esse tipo de trabalho pela própria inexperiência em trabalhar com pesquisa; pelo maior volume de leituras que precisam fazer; pelo fato de que precisam buscar as informações e fazer suas próprias elaborações e, principalmente, pela dificuldade que têm em expressar suas ideias na forma escrita. Contudo, parece que tais dificuldades não os desestimulam, alguns depoimentos deixaram transparecer que os alunos reconhecem que a experiência com pesquisa torna interessante o ato de aprender. Mas, percebemos que a preocupação em estimular a divergência e a criatividade, bem como de instalar a dúvida entre os alunos, aparece em menor significação. $\bigcirc$ discurso dos professores, muitas vezes, contempla a capacidade de reflexão do aluno. Mas há, quase sempre, uma ideia de verdade que é a do professor o que deixa transparecer 
uma forte presença do paradigma tradicional de ensino, no qual se espera que o professor seja a principal fonte de conhecimento.

Percebemos que as experiências relatadas, se cotejadas com as estratégias apontadas pelos autores mencionados no presente estudo para estimular a pesquisa no aluno, ainda são tímidas. Mesmo assim, considera-se que a pesquisa que os professores realizam com os alunos, ainda que principiante (aqui é a

\section{REFERÊNCIAS}

BENHRENS, M.A. A prática pedagógica e o desafio do paradigma emergente. Revista Brasileira de Estudos Pedagógicos, v.80, n. 196, p.383-403, 1999.

BENHRENS, M.A. O paradigma emergente e a prática pedagógica. Petrópolis: Vozes, 2005.

CAPRA, F. O ponto de mutação. São Paulo: Cultrix, 1982.

CAPRA, F. A teia da vida: uma nova compreensão científica dos sistemas vivos. São Paulo: Cultrix, 1996.

CASTRO, C.A. (Org). Conhecimento, pesquisa e práticas sociais em ciência da informação. São Luís: EDUFMA, 2007.

CUNHA, M.I. Ensino com pesquisa: a prática do professor universitário. Cadernos de Pesquisa, n.97, p.31-46, 1996.

CUNHA, M.I. Relação ensino e pesquisa. In: VEIGA, I.P.A. (Org.). Didática: o ensino e suas relações. 2. ed. Campinas: Papirus, 1997. p.115-126.

CUNHA, M.I. O professor universitário na transição de paradigmas. Araraquara: JM Editora, 1998.

DAMASCENO, M.N. A formação de novos pesquisadores: a investigação como uma construção coletiva a partir da relação teoria-prática. In: CALAZANS, J. (Org.). Iniciação científica: construindo o pensamento crítico. São Paulo: Cortez, 1999. p.13-55.

DEMO, P. Pesquisa: princípio científico e educativo. 2. ed. São Paulo: Cortez. 1991.

DEMO, P. Desafios modernos da educação. São Paulo: Cortez, 1993.

DEMO, P. Educação e qualidade. 3. ed. Campinas: Papirus, 1996.

DEMO, P. Educar pela pesquisa. 2. ed. Campinas: Autores Associados, 1997

FREIRE, P. Pedagogia da autonomia: saberes necessários à prática educativa. São Paulo: Paz e Terra, 1996. pesquisa que é considerada principiante), e o esforço para conduzi-los à condição de produzir conhecimento, constitui-se numa iniciativa louvável para fazer progredir a ideia de uma educação dialógica, onde o aluno seja o principal sujeito da aprendizagem. Se isso for uma constante nos cursos de formação de profissionais da informação, estaria-se realmente partindo para um novo paradigma de ensino nas áreas de Biblioteconomia e Ciência da Informação.

GRINSPUN, M.P.S.Z. Os novos paradigmas em educação: os caminhos viáveis para uma análise. Revista Brasileira de Pedagogia, v.75, n.179-180, p.211-242, 1994.

LUCARELLI, E. Teoria e practica como inovación em docência, investigación y atualización pedagógica. Buenos Aires: UBA/Instituto de Ciencias de la Educación, 1994. (Cuadernos de Investigación, n. 10).

MASETTO, M.T. Competência pedagógica do professor universitário. São Paulo: Summus, 2003.

MINAYO, M.C.S. et al. (Org.). Pesquisa social: teoria, método e criatividade. 7. ed. Petrópolis: Vozes, 1997.

MORIN, E. A cabeça bem-feita: repensar a reforma, reformar o pensamento. Rio de Janeiro: Bertrand Brasil, 2000a.

MORIN, E. Os sete saberes necessários à educação do futuro. São Paulo: Cortez, 2000b.

OLIVEIRA, M. Origem e evolução da ciência da informação. In: OLIVEIRA, M. Ciência da informação e biblioteconomia: novos conteúdos e espaços de atuação. Belo Horizonte: Ed. UFMG, 2005. p.9-28.

OLIVEIRA, M.; ARAÚJO, E.A. Os paradigmas da Biblioteconomia e da Ciência da Informação e os novos contextos de informação. In: CASTRO, C.A. (Org.). Ciência da informação e biblioteconomia: múltiplos discursos. São Luís: EDUFMA, 2002. Cap.2, p.36-49.

PÉREZ GÓMEZ, A. A função e formação do professor/a no ensino para a compreensão: diferentes perspectivas. In: SACRISTÁN, J.G.; PÉREZ GÓMEZ, A. Compreender e transformar o ensino. Porto Alegre: ArtMed, 1998. p.353-379.

PIMENTA, S.G.; ANASTASIOU, L.G.C.; CAVALLET, V.J. Docência no ensino superior: construindo caminhos. In: PIMENTA, S.G. (Org.). De professores, pesquisa e didática. Campinas: Papirus, 2002. p.129-144.

PRIGOGINE, I.; STENGERS, I. A nova aliança: metamorfose da ciência. Brasília: UnB, 1991. 
RODRIGUES, M.E.F. A formação profissional em biblioteconomia: superando limites e construindo possibilidades. Encontros Bibli, Florianópolis, n.13, 2002a. Disponível em: <http:// www.encontros-bibli.ufsc.br>. Acesso em: 3 jul. 2002.

RODRIGUES, M.E.F. A Pesquisa como princípio educativo na formação do profissional da informação. In: VALENTIM, M.L.P. (Org.). Formação do profissional da informação. São Paulo: Polis, 2002b. p.89-101.

RODRIGUES, M.E.F. Relação ensino-pesquisa: em discussão a formação do profissional da informação. DataGramaZero, v.3, n.5, p. 1-12, 2002c. Disponível em: <http://www.dgz.org.br>. Acesso em: 16 dez. 2002.

RODRIGUES, M.E.F.; BREGLIA, V.L.A. Das práticas aos fundamentos: o cotidiano revisitado. Informação \& Sociedade: Estudos, v.11, n. 1, p.231-249, 2001.

RODRIGUES, M.E.F; CAMPELLO, B.S. (Org.). A (re)significação do processo de ensino/aprendizagem em biblioteconomia e ciência da informação. Rio de Janeiro: Interciência, 2004.

RODRIGUES, M.E.F.; DUMONT, L.M.M. A lógica da organização e distribuição do conhecimento na universidade: implicações no processo de ensino-aprendizagem, em especial, nas áreas de biblioteconomia e ciência da informação. DataGramaZero, v.5, n.2, p.1-15, 2004. Disponível em: <http://www.dgz.org.br>. Acesso em: 28 jul. 2004.

RODRIGUES, M.E.F.; LÜCK, E.A.; BREGLIA, V.LA. O ensino com a prática da pesquisa: delineamento de uma nova proposta de formação. Transinformação, v. 14, n.1, p.41-47, 2002
SANTOS, B.S. Um discurso sobre as ciências em transição para uma ciência pós-moderna. Revista de Estudos Avançados, v.2, n. 2, p.46-70, 1988.

SANTOS, B.S. Introdução a uma ciência pós-moderna. Rio de Janeiro: Graal, 1989.

SANTOS, B.S. Pela mão de Alice: o social e o político na pós-modernidade. 5. ed. São Paulo: Cortez, 1999.

SANTOS, B.S. A crítica da razão indolente: contra o desperdício da experiência. 4. ed. São Paulo: Cortez, 2002a. v. 1.

SANTOS, B.S. Um discurso sobre as ciências. 13. ed. Porto: Afrontamento, 2002b.

SCHÖN, D.A. Formar professores como profissionais reflexivos. In: NÓVOA, A. (Coord.). Os professores e a sua formação. Lisboa: Publicações Dom Quixote, 1995. p.77-91.

SOUZA, F.C. O modelo educacional emergente e seu impacto sobre a dimensão pedagógica da ciência da informação. Palestra apresentada no I ENECIN, 6-8 de julho de 2004, Londrina: [s.n.], 2004. 21 p.

TRANSINFORMAÇÃO. Programa de Pós-Graduação em Ciência da Informação, v. 14, n. 1, 2002. 106p. Número especial.

TRANSINFORMAÇÃO. Programa de Pós-Graduação em Ciência da Informação, v. 15, n.2, 2003. 285p. Número Especial.

ZEICHNER, K. Novos caminhos para o praticum: uma perspectiva para os anos 90. In: NÓVOA, A. (Coord.). Os professores e a sua formação. Lisboa: Publicações Dom Quixote, 1995. p.115-138. 
